\title{
Isolation, morphological identification and in vitro antibacterial activity of endophytic bacteria isolated from Azadirachta indica (neem) leaves
}

\author{
Ankit Kumar Singh ${ }^{1}$, Rajesh Kumar Sharma ${ }^{1}$, Varsha Sharma ${ }^{2}$, Tanmay Singh ${ }^{1}$, Rajesh Kumar ${ }^{3}$ and Dimple Kumari ${ }^{4}$
}

1. Department of Veterinary Pharmacology and Toxicology, College of Veterinary Science and Animal Husbandry, Nanaji Deshmukh Veterinary Science University, Jabalpur - 482 001, Madhya Pradesh, India; 2. Department of Veterinary Microbiology, College of Veterinary Science and Animal Husbandry, Nanaji Deshmukh Veterinary Science University, Jabalpur - 482 001, Madhya Pradesh, India; 3. Department of Animal Nutrition, College of Veterinary Science and Anima Husbandry, Nanaji Deshmukh Veterinary Science University, Jabalpur - 482 001, Madhya Pradesh, India; 4. Department of Veterinary Biotechnology, College of Veterinary Science and Animal Husbandry, Nanaji Deshmukh Veterinary Science University, Jabalpur - 482 001, Madhya Pradesh, India.

Corresponding author: Rajesh Kumar Sharma, e-mail: drrksvet2012@gmail.com,

Co-authors: AKS: ankitsingh.r7@gmail.com,VS: drvsvet2012@gmail.com, TS: tanmaytanu.90@gmail.com, RK: rajeshkumarmahla46@gmail.com,DK: d7k7r7@gmail.com

Received: 13-06-2016, Accepted: 23-03-2017, Published online: 11-05-2017

doi: 10.14202/vetworld.2017.510-516 How to cite this article: Singh AK, Sharma RK, Sharma V, Singh T, Kumar R, Kumari D (2017) Isolation, morphological identification and in vitro antibacterial activity of endophytic bacteria isolated from Azadirachta indica (neem) leaves, Veterinary World, 10(5): 510-516.

\begin{abstract}
Aim: The objective of this study was to isolate endophytic bacteria from Azadirachta indica (neem) leaves, their identification and investigate their antibacterial activity against three Gram-positive bacteria, Staphylococcus aureus, Streptococcus pyogenes and Bacillus cereus and Gram-negative bacteria Escherichia coli, Salmonella Typhimurium and Klebsiella pneumoniae.

Materials and Methods: Fresh leaves of $A$. indica (neem) was procured from the Department of Botany, JNKVV, Jabalpur. Five samples were taken, and each sample was divided into five subsamples and separated for further isolation of endophytic bacteria. For sterilization leaves were treated with double distilled water, $0.1 \%$ sodium hypochlorite, $0.01 \%$ bavistin, $0.05 \%$ and $70 \%$ ethanol. Sterilized leaves of the plants were embedded in Kings B (KB) petri plates and incubated at $37^{\circ} \mathrm{C}$ for $24 \mathrm{~h}$. Characterization of the bacteria was done according to its morphology and by Gram-staining. After that, a single colony was transferred into brain heart infusion (BHI) broth and incubated at $37^{\circ} \mathrm{C}$ for $24 \mathrm{~h}$. The antibacterial effect was studied by the disk diffusion method with known antibiotic ciprofloxacin $(\mathrm{Ci})$ as standard.

Results: A total of 25 bacterial isolates from $A$. indica (neem) were obtained and identified morphologically. Most of the samples on KB media depicted irregular shape, flat elevation, undulated, rough, opaque, and white in color. Most of the samples on blood agar showed irregular, raise elevation, undulated, smooth, opaque and all the isolates were nonhemolytic and nonchromogenic. The growth of endophytic bacteria in BHI broth were all isolates showed turbidity. The microscopic examination revealed that maximum isolates were Gram-positive and rod shaped. Good antibacterial activity was observed against S. aureus, Streptococcus pyogenes, E. coli, Salmonella Typhimurium, and K. pneumoniae.
\end{abstract}

Conclusions: Endophytic bacteria are present in leaves of $A$. indica (neem) and it possesses antibacterial activity against few Gram-positive and Gram-negative bacteria.

Keywords: antibacterial activity, Azadirachta indica (neem), ciprofloxacin, endophytic bacteria, leaves.

\section{Introduction}

An increase in the number of people in the world, having health problems leading to various types of cancers, drug-resistant bacteria, parasitic protozoans and fungal infection is a cause for alarm. An intensive search for newer and more effective agents to deal with these disease problems is now underway and endophytes are a novel source of potentially useful medicinal compounds.

Endophytes are microorganisms, including bacteria that live in the intercellular spaces of plant

Copyright: Singh, et al. Open Access. This article is distributed under the terms of the Creative Commons Attribution 4.0 International License (http://creativecommons.org/licenses/by/4.0/), which permits unrestricted use, distribution, and reproduction in any medium, provided you give appropriate credit to the original author(s) and the source, provide a link to the Creative Commons license, and indicate if changes were made. The Creative Commons Public Domain Dedication waiver (http://creativecommons.org/ publicdomain/zero/1.0/) applies to the data made available in this article, unless otherwise stated. without showing any disease symptoms to the host plant [1]. Many studies have emphasized endophytes from medicinal plants and their application in different areas [2]. Recently, many known, as well as new endophytic bioactive metabolites, possessing a wide variety of biological activities as antibiotic, antiviral, anticancer, anti-inflammatory, antioxidant, etc., have been identified [3].

Azadirachta indica (neem) is a divine tree mainly cultivated in the Indian subcontinent, belonging to the botanical family Meliaceae, commonly known as neem [4]. All the parts of $A$. indica tree are commonly used in traditional Indian medicine for household remedy against various human diseases. In India, various parts of neem (leaf, bark, and seeds) are used as a traditional medicine. Different parts of neem have been shown to exhibit wide pharmacological activities such as antibacterial [5], antiviral [6], anti-inflammatory 
activity [7], anti-carcinogenic activity [8], parasitic disease [9], and skin disease [8].

The objective of this study was to isolate endophytic bacteria from neem leaves, their identification and investigate their antibacterial activity against three Gram-positive bacteria, Staphylococcus aureus, Streptococcus pyogenes and Bacillus cereus and Gram-negative bacteria Escherichia coli, Salmonella Typhimurium, and Klebsiella pneumoniae.

\section{Materials and Methods}

Ethical approval

In this work, no animals were used therefore there was no requirement of ethical approval.

\section{Plant material}

Fresh leaves of $A$. indica (neem) were procured from the Department of Botany, JNKVV, Jabalpur. Fresh, healthy plant leaves were collected by selected medicinal plants, viz., A. indica (neem). Five samples from each tree were taken and each sample was divided into five subsamples and separated for further isolation of endophytic bacteria. Samples were immediately brought to the laboratory and were used within $24 \mathrm{~h}$ and finally processed for isolation of endophytic bacteria.

\section{Sterilization of leaves}

The sterilization of leaves and isolation of endophytic bacteria from the leaves was done according to Mahajan et al. [10], with some modifications. The leaves were treated with double distilled water for 2-3 min, then surface sterilized with $0.1 \%$ sodium hypochlorite for $5 \mathrm{~min}$, washed with double distilled water for 2-3 min. Later, surface sterilization was done with $0.01 \%$ bavistin and was kept in distilled water for $5 \mathrm{~min}$. For further sterilization, the leaves were exposed to $0.05 \%$ streptomycin followed by treatment with double distilled water for $5 \mathrm{~min}$. Then, the leaves were exposed to $70 \%$ ethanol and again were kept in double distilled water for $5 \mathrm{~min}$ and were excised with autoclaved scalpel and forceps in the laminar air flow chamber, then air dried in laminar flow.

\section{Sterility check}

To confirm that the surface of leaves were effectively sterilized $1 \mathrm{ml}$ of the sterile distilled water that was used in the final rinse of surface sterilization procedures were planted onto nutrient agar media and incubated at $37^{\circ} \mathrm{C}$ for $24 \mathrm{~h}$. Bacterial growths were observed after $24 \mathrm{~h}$. Furthermore, surface sterilized leaves were rolled on nutrient agar plates and incubated at $37^{\circ} \mathrm{C}$ for $24 \mathrm{~h}$ and checked for possible microbial growth.

\section{Preparation and sterilization of media}

King's B (KB) media, Mueller-Hinton media, blood agar media, and brain heart infusion (BHI) broth were prepared by adding agar in the distilled water. Hotplate was used for the proper mixing of media and autoclaved at $121^{\circ} \mathrm{C}$ for $15-20 \mathrm{~min}$ at $15 \mathrm{lbs}$.

\section{Inoculation of leaves}

The media was poured into different autoclaved petri plates and leaves of the plants were embedded in petri plates. These plates were then incubated at $37^{\circ} \mathrm{C}$ for $24 \mathrm{~h}$. Characterization of the bacteria was done according to its morphology and by Gram-staining. After that, a single colony was transferred into BHI broth and incubated at $37^{\circ} \mathrm{C}$ for $24 \mathrm{~h}$.

\section{Purification of endophytic bacteria}

For purification of endophytic bacteria subculturing was mainly done by streaking a loop full of $\mathrm{BHI}$ broth on the fresh pre-solidified blood agar plates and then incubated at $37^{\circ} \mathrm{C}$ for $24 \mathrm{~h}$. After incubation, the colonies were transferred into BHI broth and then incubated at $37^{\circ} \mathrm{C}$ for $24 \mathrm{~h}$ and purity is checked by Gram-stain and stored at $-20^{\circ} \mathrm{C}$ in deep freeze for further work.

\section{Antibacterial activity of endophytic bacteria \\ a. In vitro study.}

\section{Procurement of known culture (Table-1) Preparation of inoculums}

The above prepared bacterial inoculums were evenly spread on sterile Mueller-Hinton agar plates as described by Bauer et al. [11], and antibacterial effect was studied by the disk diffusion method in these plates. The known antibiotic ciprofloxacin (Ci) was simultaneously used and placed as a control for antibiotic sensitivity. The dried disks were immediately used and incubated at $37^{\circ} \mathrm{C}$ for $24 \mathrm{~h}$.

\section{Preparation of antibacterial disk}

For determination of antibacterial activity of endophytic bacteria, broths was centrifuged at $4^{\circ} \mathrm{C}$ at $12,000 \mathrm{rpm}$ for $30 \mathrm{~min}$. Supernatant of each of these broths was taken, sterile disks were soaked in these broths in sterile test tubes for $24 \mathrm{~h}$ and dried in laminar flow. After drying, the disks were used immediately for disk impregnation in the inoculated plates as described by Kirubaharan et al. [12] with slight modifications. Ci disk were used as a control drug to compare the effect of treatment during in vitro study.

\section{Antibacterial test}

The prepared bacterial inoculums were evenly spread on a sterile Mueller-Hinton agar plate as per method described by Bauer et al. [11]. The known antibiotic $\mathrm{Ci}$ was simultaneously placed as a control for antibiotic sensitivity. The dried disk was incubated at $37^{\circ} \mathrm{C}$ for $24 \mathrm{~h}$. Results were recorded as positive

Table-1: List of procured bacterial culture.

\begin{tabular}{lc}
\hline Bacteria & ATCC catalogue No. \\
\hline Escherichia coli & 25,922 \\
Klebsiella pneumoniae & 700,603 \\
Salmonella Typhimurium & 13,311 \\
Bacillus cereus & 11,778 \\
Staphylococcus aureus & 6538 \\
Streptococcus pyogenes & 12,386 \\
\hline ATCC: American Type Culture Collection
\end{tabular}

ATCC: American Type Culture Collection 
(growth) or negative (no growth) and zone of inhibition of growth exerted by these impregnated disks.

\section{Results}

This study was conducted with a view to isolate and characterizes the endophytic bacterial diversity from $A$. indica (neem). 25 bacterial isolates from $A$. indica (neem) were obtained and identified morphologically. These endophytic bacteria were evaluated for in vitro antibacterial activity.

The sterilized leaves of $A$. indica (neem) were put in the $\mathrm{KB}$ media and incubated at $37^{\circ} \mathrm{C}$ at $24 \mathrm{~h}$. The morphological characterization of endophytic bacterial isolates exhibited diverse colony shape, color margin and texture, including round to irregular colonies and white and yellow colonies with irregular and wavy margins. The endophytic bacterial isolates recovered from KB media showed soft and mucoid colonies.

\section{Preliminary characterization of isolated endophytic bacteria}

Growth of endophytic bacteria in KB medium

Growth characteristics of endophytic bacteria isolated from neem leaves showed that $84 \%$ were irregular in shape while $16 \%$ circular in shape, $64 \%$ were flat elevation on petri plate while $36 \%$ raised elevation, margin of the $72 \%$ colonies were undulated while $28 \%$ entire, the surface of the growth was rough in $72 \%$ while $16 \%$ entire and $12 \%$ smooth and $96 \%$ growth were opaque and white in color (Table-2).

Growth of endophytic bacteria on 5\% sheep blood agar medium

Colonies of endophytic bacteria grown on $\mathrm{KB}$ agar were transferred to the $5 \%$ sheep blood agar plates and incubated at $37^{\circ} \mathrm{C}$ for $24 \mathrm{~h}$. The growth of endophytic bacteria from $A$. indica (neem) was studied.

Growth characteristics of endophytic bacteria isolated from neem leaves presented that $76 \%$ were irregular in shape while $34 \%$ circular in shape, $84 \%$ were raised elevation on petri plate while $16 \%$ flat elevation, margin of the $88 \%$ colonies were undulated while $12 \%$ entire, the surface of the growth was smooth in $92 \%$ while $8 \%$ rough; the growth was opaque in $96 \%$ isolates. All the isolates were nonhemolytic and nonchromogenic (Table-3).

\section{Growth of endophytic bacteria in BHI broth}

Colonies of endophytic bacteria grown on blood agar were transferred to the sterile BHI broth tubes and incubated at $37^{\circ} \mathrm{C}$ for $24 \mathrm{~h}$. The growth of endophytic bacteria from $A$. indica (neem).

Endophytic bacteria from neem leaves shown characteristics as $100 \%$ isolates with turbidity, $92 \%$ isolates with flocculent growth and 100\% isolates with pellicle formation. No sediment formation was seen in $88 \%$ isolates and $52 \%$ isolates showed ring formation (Table-4).

\section{Microscopic examination}

The microscopic examination of endophytic bacteria was done by using Gram-stain. The results of Gram-staining are follows: 88\% isolates shown Grampositive reaction while $12 \%$ were Gram-negative, $88 \%$ endophytic bacteria were rod shape, and $12 \%$ were cocci. Microscopic examination showed that more than one type of endophytic bacteria was present in $84 \%$ of isolate (Table-5).

Table-2: Growth of endophytic bacteria isolated from Azadirachta indica (neem) on KB media.

\begin{tabular}{|c|c|c|c|c|c|c|}
\hline Isolate No. & Form & Elevation & Margin & Surface & Opacity & Chromogenesis \\
\hline N1a & Irregular & Flat & Undulated & Rough & Opaque & Absent \\
\hline N1b & Irregular & Raised & Undulated & Rough & Opaque & Absent \\
\hline $\mathrm{N} 1 \mathrm{C}$ & Irregular & Flat & Undulated & Rough & Opaque & Absent \\
\hline N1d & Circular & Flat & Entire & Dull & Opaque & Absent \\
\hline N1e & Irregular & Raised & Undulated & Rough & Opaque & Absent \\
\hline $\mathrm{N} 2 \mathrm{a}$ & Irregular & Flat & Undulated & Dull & Opaque & Absent \\
\hline $\mathrm{N} 2 \mathrm{~b}$ & Irregular & Raised & Undulated & Rough & Opaque & Absent \\
\hline $\mathrm{N} 2 \mathrm{C}$ & Irregular & Raised & Undulated & Smooth & Opaque & Absent \\
\hline $\mathrm{N} 2 \mathrm{~d}$ & Irregular & Flat & Undulated & Rough & Opaque & Absent \\
\hline $\mathrm{N} 2 \mathrm{e}$ & Irregular & Flat & Entire & Smooth & Opaque & Absent \\
\hline N3a & Irregular & Flat & Undulated & Rough & Glistening & Absent \\
\hline N3b & Irregular & Flat & Undulated & Rough & Opaque & Absent \\
\hline N3c & Circular & Flat & Entire & Rough & Opaque & Absent \\
\hline N3d & Circular & Flat & Undulated & Smooth & Opaque & Absent \\
\hline N3e & Irregular & Flat & Entire & Rough & Opaque & Green \\
\hline $\mathrm{N} 4 \mathrm{a}$ & Irregular & Raised & Undulated & Rough & Opaque & Absent \\
\hline $\mathrm{N} 4 \mathrm{~b}$ & Irregular & Flat & Undulated & Rough & Opaque & Absent \\
\hline $\mathrm{N} 4 \mathrm{C}$ & Irregular & Flat & Entire & Smooth & Opaque & Absent \\
\hline $\mathrm{N} 4 \mathrm{~d}$ & Irregular & Flat & Undulated & Dull & Opaque & Absent \\
\hline $\mathrm{N} 4 \mathrm{e}$ & Irregular & Flat & Undulated & Rough & Opaque & Absent \\
\hline N5a & Irregular & Raised & Entire & Rough & Opaque & Absent \\
\hline N5b & Irregular & Raised & Undulated & Dull & Opaque & Absent \\
\hline N5c & Irregular & Flat & Entire & Rough & Opaque & Absent \\
\hline N5d & Circular & Raised & Undulated & Rough & Opaque & Absent \\
\hline N5e & Irregular & Flat & Undulated & Rough & Opaque & Absent \\
\hline
\end{tabular}


Available at www.veterinaryworld.org/Vol.10/May-2017/7.pdf

Table-3: Growth of endophytic bacteria isolated from Azadirachta indica (neem) on 5\% sheep blood agar.

\begin{tabular}{|c|c|c|c|c|c|c|}
\hline Sample No. & Form & Elevation & Margin & Surface & Opacity & Chromogenesis \\
\hline N1a & Irregular & Raised & Undulated & Smooth & Opaque & Absent \\
\hline N1b & Irregular & Raised & Undulated & Smooth & Opaque & Absent \\
\hline $\mathrm{N} 1 \mathrm{C}$ & Irregular & Raised & Undulated & Smooth & Opaque & Absent \\
\hline N1d & Circular & Raised & Undulated & Smooth & Opaque & Absent \\
\hline N1e & Irregular & Raised & Undulated & Smooth & Opaque & Absent \\
\hline $\mathrm{N} 2 \mathrm{a}$ & Circular & Raised & Undulated & Smooth & Opaque & Absent \\
\hline $\mathrm{N} 2 \mathrm{~b}$ & Irregular & Raised & Undulated & Smooth & Opaque & Absent \\
\hline $\mathrm{N} 2 \mathrm{C}$ & Irregular & Flat & Undulated & Smooth & Opaque & Absent \\
\hline $\mathrm{N} 2 \mathrm{~d}$ & Irregular & Raised & Undulated & Smooth & Opaque & Absent \\
\hline $\mathrm{N} 2 \mathrm{e}$ & Irregular & Raised & Undulated & Smooth & Opaque & Absent \\
\hline N3a & Circular & Raised & Undulated & Smooth & Glistening & Absent \\
\hline N3b & Irregular & Raised & Undulated & Smooth & Opaque & Absent \\
\hline N3c & Circular & Flat & Entire & Rough & Opaque & Absent \\
\hline N3d & Circular & Raised & Undulated & Smooth & Opaque & Absent \\
\hline N3e & Irregular & Raised & Undulated & Smooth & Opaque & Green \\
\hline $\mathrm{N} 4 \mathrm{a}$ & Irregular & Raised & Undulated & Smooth & Opaque & Absent \\
\hline $\mathrm{N} 4 \mathrm{~b}$ & Irregular & Raised & Undulated & Smooth & Opaque & Absent \\
\hline $\mathrm{N} 4 \mathrm{C}$ & Irregular & Raised & Entire & Smooth & Opaque & Absent \\
\hline $\mathrm{N} 4 \mathrm{~d}$ & Irregular & Flat & Undulated & Smooth & Opaque & Absent \\
\hline $\mathrm{N} 4 \mathrm{e}$ & Irregular & Raised & Undulated & Smooth & Opaque & Absent \\
\hline N5a & Irregular & Raised & Entire & Smooth & Opaque & Absent \\
\hline N5b & Irregular & Raised & Undulated & Rough & Opaque & Absent \\
\hline N5c & Irregular & Raised & Undulated & Smooth & Opaque & Absent \\
\hline N5d & Circular & Raised & Undulated & Smooth & Opaque & Absent \\
\hline N5e & Irregular & Flat & Undulated & Smooth & Opaque & Absent \\
\hline
\end{tabular}

Table-4: Growth of endophytic bacteria isolated from Azadirachta indica (neem) on BHI broth.

\begin{tabular}{|c|c|c|c|c|c|}
\hline Isolate No. & Turbidity & Flocculant & Pellicle & Sediment & Ring formation \\
\hline $\mathrm{N} 1 \mathrm{a}$ & Present & Present & Present & Absent & Absent \\
\hline N1b & Present & Present & Present & Absent & Absent \\
\hline N1c & Present & Present & Present & Absent & Present \\
\hline N1d & Present & Present & Present & Absent & Absent \\
\hline N1e & Present & Absent & Present & Present & Present \\
\hline $\mathrm{N} 2 \mathrm{a}$ & Present & Present & Present & Absent & Absent \\
\hline $\mathrm{N} 2 \mathrm{~b}$ & Present & Present & Present & Absent & Present \\
\hline N2C & Present & Present & Present & Absent & Present \\
\hline $\mathrm{N} 2 \mathrm{~d}$ & Present & Present & Present & Absent & Present \\
\hline N2e & Present & Present & Present & Absent & Absent \\
\hline N3a & Present & Present & Present & Absent & Absent \\
\hline N3b & Present & Present & Present & Absent & Present \\
\hline N3c & Present & Absent & Present & Absent & Present \\
\hline N3d & Present & Present & Present & Absent & Absent \\
\hline N3e & Present & Present & Present & Absent & Present \\
\hline $\mathrm{N} 4 \mathrm{a}$ & Present & Present & Present & Absent & Absent \\
\hline $\mathrm{N} 4 \mathrm{~b}$ & Present & Present & Present & Present & Present \\
\hline $\mathrm{N} 4 \mathrm{C}$ & Present & Present & Present & Absent & Absent \\
\hline $\mathrm{N} 4 \mathrm{~d}$ & Present & Absent & Present & Absent & Present \\
\hline $\mathrm{N} 4 \mathrm{e}$ & Present & Present & Present & Absent & Absent \\
\hline N5a & Present & Present & Present & Absent & Absent \\
\hline N5b & Present & Present & Present & Absent & Present \\
\hline N5c & Present & Present & Present & Present & Absent \\
\hline N5d & Present & Present & Present & Absent & Present \\
\hline N5e & Present & Present & Present & Absent & Absent \\
\hline
\end{tabular}

$\mathrm{BHI}=$ Brain heart infusion

\section{In vitro antibacterial activity}

\section{Antibacterial sensitivity}

The antibacterial activity of endophytic bacteria was evaluated against various Gram-positive and Gram-negative pathogenic bacteria, namely, B. cereus, S. aureus, Streptococcus pyogenes, E. coli, K. pneumoniae, and Salmonella Typhimurium. Results were recorded for zone of inhibition around the disk. The inhibitory zone around the disk indicated absence of bacterial growth reported as sensitive and absence of zone reported as resistant.

\section{For Gram-positive bacteria}

The in vitro antibacterial activities of the endophytic bacteria against different Gram-positive bacteria are shown in Table-6. The endophytic bacteria isolated 
Table-5: Gram-staining of endophytic bacteria isolated from Azadirachta indica (neem).

\begin{tabular}{lllc}
\hline Isolate No. & Gram-staining & Shape & Types of bacteria \\
\hline N1a & Positive & Bacillus & $<1$ \\
N1b & Positive & Bacillus & $<1$ \\
N1c & Positive & Bacillus & $<1$ \\
N1d & Positive & Bacillus & 1 \\
N1e & Negative & Cocci & $<1$ \\
N2a & Positive & Bacillus & $<1$ \\
N2b & Positive & Bacillus & $<1$ \\
N2c & Positive & Bacillus & $<1$ \\
N2d & Positive & Bacillus & $<1$ \\
N2e & Positive & Bacillus & $<1$ \\
N3a & Positive & Bacillus & 1 \\
N3b & Positive & Bacillus & $<1$ \\
N3c & Positive & Bacillus & $<1$ \\
N3d & Positive & Bacillus & $<1$ \\
N3e & Positive & Bacillus & $<1$ \\
N4a & Positive & Cocci & $<1$ \\
N4b & Negative & Bacillus & $<1$ \\
N4c & Positive & Bacillus & $<1$ \\
N4d & Positive & Bacillus & 1 \\
N4e & Positive & Bacillus & $<1$ \\
N5a & Positive & Cocci & $<1$ \\
N5b & Negative & Bacillus & $<1$ \\
N5c & Positive & Bacillus & $<1$ \\
N5d & Positive & Bacillus & $<1$ \\
N5e & Positive & Bacillus & 1 \\
\hline & & &
\end{tabular}

Table-6: In vitro antibacterial activity of endophytic bacteria isolated from Azadirachta indica (neem) against Gram-positive bacteria.

\begin{tabular}{llll}
\hline Isolate No. & $\begin{array}{l}\text { Staphylococcus } \\
\text { aureus }\end{array}$ & $\begin{array}{l}\text { Streptococcus } \\
\text { pyogenes }\end{array}$ & $\begin{array}{l}\text { Bacillus } \\
\text { cereus }\end{array}$ \\
\hline N1a & $\mathrm{S}$ & $\mathrm{S}$ & $\mathrm{R}$ \\
N1b & $\mathrm{S}$ & $\mathrm{S}$ & $\mathrm{R}$ \\
$\mathrm{N} 1 \mathrm{c}$ & $\mathrm{S}$ & $\mathrm{R}$ & $\mathrm{R}$ \\
N1d & $\mathrm{S}$ & $\mathrm{S}$ & $\mathrm{R}$ \\
N1e & $\mathrm{R}$ & $\mathrm{S}$ & $\mathrm{R}$ \\
N2a & $\mathrm{S}$ & $\mathrm{S}$ & $\mathrm{S}$ \\
N2b & $\mathrm{S}$ & $\mathrm{S}$ & $\mathrm{R}$ \\
N2c & $\mathrm{S}$ & $\mathrm{S}$ & $\mathrm{R}$ \\
N2d & $\mathrm{S}$ & $\mathrm{S}$ & $\mathrm{R}$ \\
N2e & $\mathrm{S}$ & $\mathrm{R}$ & $\mathrm{R}$ \\
N3a & $\mathrm{R}$ & $\mathrm{S}$ & $\mathrm{R}$ \\
N3b & $\mathrm{S}$ & $\mathrm{S}$ & $\mathrm{R}$ \\
N3c & $\mathrm{S}$ & $\mathrm{S}$ & $\mathrm{R}$ \\
N3d & $\mathrm{S}$ & $\mathrm{S}$ & $\mathrm{R}$ \\
N3e & $\mathrm{S}$ & $\mathrm{S}$ & $\mathrm{S}$ \\
N4a & $\mathrm{S}$ & $\mathrm{R}$ & $\mathrm{R}$ \\
N4b & $\mathrm{S}$ & $\mathrm{S}$ & $\mathrm{R}$ \\
N4c & $\mathrm{R}$ & $\mathrm{S}$ & $\mathrm{R}$ \\
N4d & $\mathrm{S}$ & $\mathrm{S}$ & $\mathrm{R}$ \\
N4e & $\mathrm{R}$ & $\mathrm{S}$ & $\mathrm{R}$ \\
N5a & $\mathrm{S}$ & $\mathrm{S}$ & $\mathrm{R}$ \\
N5b & $\mathrm{S}$ & $\mathrm{S}$ & $\mathrm{R}$ \\
N5c & $\mathrm{R}$ & $\mathrm{R}$ & $\mathrm{R}$ \\
N5d & $\mathrm{S}$ & $\mathrm{S}$ & $\mathrm{R}$ \\
N5e & $\mathrm{S}$ & $\mathrm{S}$ & $\mathrm{R}$ \\
\hline & & & \\
\hline
\end{tabular}

from $A$. indica (neem) shown antibacterial activity as $80 \%$ of isolates inhibited growth of $S$. aureus, $84 \%$ of isolates inhibited growth of $S$. pyogenes, and $8 \%$ isolates inhibited growth of $B$. cereus.

\section{For Gram-negative bacteria}

The in vitro antibacterial activities of endophytic bacteria against different Gram-negative bacteria have been shown in Table-7. The endophytic bacteria isolated from $A$. indica (neem) shown antibacterial activity as $92 \%$ of isolates inhibited growth of E. coli, $88 \%$ of isolates inhibited growth of Salmonella Typhimurium, and $88 \%$ isolates inhibited growth of K. pneumoniae.

\section{Over all in vitro antibacterial activity of endophytic bacterial isolates}

Out of 25 isolates from A. indica (neem) 20 isolates were effective against $S$. aureus, 21 against $S$. pyogenes, 2 against $B$. cereus, 23 against $E$. coli, 22 against Salmonella Typhimurium, and 22 against K. pneumoniae (Table-8).

\section{Discussion}

About 25 strains of endophytic bacteria were isolated from leaves of $A$. indica (neem). Endophytic bacteria are found in virtually every plant on earth [13]. Different plant parts such as root, stem and nodule [14], leaves, stems and root [15] can also be used for isolation of endophytic bacteria. Costa et al. [16] had isolated culturable endophytic bacteria from common bean (Phaseolus vulgaris) leaves.

The preliminary identification of the bacterial isolates was done based on various morphological features of isolated endophytic bacteria. The colony characteristics of endophytic bacteria isolated from neem are having irregular in shape while flat elevation on petri plate, margin of the colonies were undulated; the surface of the growth was rough, opaque and white in color. The microscopic examination of endophytic bacteria has shown that among the endophytic bacteria isolated from neem, $88 \%$ isolate were Gram-positive while $12 \%$ Gram-negative, $88 \%$ endophytic bacteria were rod shape and $12 \%$ were cocci, microscopic examination showed that there were more than one type of endophytic bacteria present in $84 \%$ of isolate.

The isolation of endophytic bacteria was in agreement with the findings of Hung and Annapurna [14] and had found equal percentages of Gram-positive (49\%) and Gram-negative (51\%) bacteria. Sobral et al. [15] and Ebrahimia et al. [17] have also found equal percentage of Gram-positive and Gram-negative bacteria. However, Bahgat et al. [18] found the 90\% of Gram-positive bacteria.

As summarized in results antibacterial activity of endophytic bacteria was calculated by the presence of zone of inhibition produced by endophytic bacteria against pathogenic bacteria. All the isolates from endophytic bacteria were screened for the antibacterial activity against pathogenic bacteria $B$. cereus, S. aureus, Streptococcus pyogenes, E. coli, K. pneumoniae, and Salmonella Typhimurium.

The overall in vitro antibacterial results shown that maximum sensitivity was observed against $E$. coli. 
Table-7: In vitro antibacterial activity of endophytic bacteria isolated from Azadirachta indica (neem) against Gram-negative bacteria.

\begin{tabular}{|c|c|c|c|}
\hline Isolate No. & $\begin{array}{l}\text { Escherichia } \\
\text { coli }\end{array}$ & $\begin{array}{l}\text { Salmonella } \\
\text { Typhimurium }\end{array}$ & $\begin{array}{l}\text { Klebsiella } \\
\text { pneumoniae }\end{array}$ \\
\hline $\mathrm{N} 1 \mathrm{a}$ & $\mathrm{S}$ & $\mathrm{S}$ & $\mathrm{s}$ \\
\hline N1b & $\mathrm{S}$ & $S$ & $\mathrm{~S}$ \\
\hline N1c & $\mathrm{S}$ & $\mathrm{S}$ & $\mathrm{S}$ \\
\hline N1d & $\mathrm{S}$ & $\mathrm{S}$ & $\mathrm{R}$ \\
\hline N1e & $\mathrm{R}$ & $\mathrm{S}$ & $\mathrm{S}$ \\
\hline $\mathrm{N} 2 \mathrm{a}$ & $\mathrm{S}$ & $\mathrm{S}$ & $\mathrm{S}$ \\
\hline $\mathrm{N} 2 \mathrm{~b}$ & $\mathrm{~S}$ & $\mathrm{R}$ & $\mathrm{S}$ \\
\hline $\mathrm{N} 2 \mathrm{C}$ & $\mathrm{S}$ & $\mathrm{S}$ & $\mathrm{S}$ \\
\hline $\mathrm{N} 2 \mathrm{~d}$ & $\mathrm{~S}$ & $\mathrm{~S}$ & $\mathrm{~S}$ \\
\hline $\mathrm{N} 2 \mathrm{e}$ & $\mathrm{S}$ & $\mathrm{S}$ & $\mathrm{S}$ \\
\hline N3a & $\mathrm{S}$ & $\mathrm{S}$ & $\mathrm{S}$ \\
\hline N3b & $\mathrm{S}$ & $\mathrm{S}$ & $\mathrm{S}$ \\
\hline N3c & $\mathrm{S}$ & $\mathrm{R}$ & $\mathrm{S}$ \\
\hline N3d & $\mathrm{S}$ & $\mathrm{S}$ & $\mathrm{S}$ \\
\hline N3e & $\mathrm{S}$ & $\mathrm{S}$ & $\mathrm{S}$ \\
\hline $\mathrm{N} 4 \mathrm{a}$ & $\mathrm{S}$ & $\mathrm{S}$ & $\mathrm{R}$ \\
\hline $\mathrm{N} 4 \mathrm{~b}$ & $\mathrm{~S}$ & $\mathrm{~S}$ & $\mathrm{~S}$ \\
\hline $\mathrm{N} 4 \mathrm{C}$ & $\mathrm{R}$ & $\mathrm{S}$ & $\mathrm{S}$ \\
\hline $\mathrm{N} 4 \mathrm{~d}$ & $\mathrm{~S}$ & $\mathrm{~S}$ & $\mathrm{~S}$ \\
\hline $\mathrm{N} 4 \mathrm{e}$ & $\mathrm{S}$ & $\mathrm{S}$ & $\mathrm{S}$ \\
\hline N5a & $\mathrm{S}$ & $\mathrm{S}$ & $\mathrm{S}$ \\
\hline N5b & $\mathrm{S}$ & $\mathrm{R}$ & $\mathrm{R}$ \\
\hline $\mathrm{N} 5 \mathrm{C}$ & $\mathrm{S}$ & $\mathrm{S}$ & $\mathrm{S}$ \\
\hline $\mathrm{N} 5 \mathrm{~d}$ & $\mathrm{~S}$ & $\mathrm{~S}$ & $\mathrm{~S}$ \\
\hline $\mathrm{N} 5 \mathrm{e}$ & $\mathrm{S}$ & $\mathrm{S}$ & $\mathrm{S}$ \\
\hline
\end{tabular}

Table-8: Overall in vitro antibacterial activity of endophytic bacterial isolates.

\begin{tabular}{ll}
\hline Samples & Activity against \\
\hline N1a, N1b, N1c, N1d, N2a, N2b, & Staphylococcus aureus \\
N2c, N2d, N2e, N3b, N3c, N3d, & \\
N3e, N4a, N4b, N4d, N4e, N5b, & \\
N5d, N5e & \\
N1a, N1b, N1d, N1e, N2a, N2b, & Streptococcus \\
N2c, N2d, N3a, N3b, N3c, N3d, & pyogenes \\
N3e, N4b, N4c, N4d, N4e, N5a, & \\
N5b, N5d, N5e & \\
N2a, N3e & \\
N1a, N1b, N1c, N1d, N2a, N2b, & Escherichia coli \\
N2c, N2d, N2e, N3a, N3b, N3c, & \\
N3d, N3e, N4a, N4b, N4d, N4e, & \\
N5a, N5b, N5c, N5d, N5e & \\
N1a, N1b, N1c, N1d, N1e, N2a, & Salmonella \\
N2c, N2d, N2e, N3a, N3b, N3d, & Typhimurium \\
N3e, N4a, N4b, N4c, N4d, N4e, & \\
N5a, N5c, N5d, N5e & \\
N1a, N1b, N1c, N1e, N2a, N2b, & Klebsiella pneumoniae \\
N2c, N2d, N2e, N3a, N3b, N3c, & \\
N3d, N3e, N4b, N4c, N4d, N4e, & \\
N5a, N5c, N5d, N5e & \\
\hline
\end{tabular}

Most of the isolates from neem had shown antibacterial activity against both Gram-positive ( $S$. aureus, and S. pyogenes) and Gram-negative bacteria (E. coli, Salmonella Typhimurium, and K. pneumoniae).

Verma et al. [19] observed antibacterial activity of endophytic actinomycetes from $A$. indica against E. coli. Ebrahimia et al. [17] observed antibacterial activity of endophytic bacteria isolated from leaves of Hypericum scabrum against $S$. aureus. Jalgaonwala et al. [20] observed antibacterial activity of endophytic bacteria isolated from roots of Aloe vera possess strong antibacterial activity against $S$. typhi in dual culture assay. Roy and Banerjee [21] isolated endophytic bacteria from a medicinal plant Vinca rosea. One of the isolated endophytes produced potential antimicrobial activity against $B$. cereus, $K$. pneumoniae, and E. coli. Pal et al. [22] reported the antimicrobial activity of the bacterial endophytes of Passiflora foetida indicating the inhibitory effect of the majority of the isolates against E. coli, S. aureus, and $K$. pneumoniae. This study is also very near to all the above authors.

\section{Conclusion}

Endophytic bacteria were present in leaves of $A$. indica (neem), Gram-positive rod-shaped bacteria were present in leaves of $A$. indica (neem). Endophytic bacteria from neem possess maximum antibacterial activity against $S$. aureus, $S$. pyogenes, E. coli, Salmonella Typhimurium, and K. pneumoniae.

\section{Authors' Contributions}

AKS, RKS and VS planned and design the study and done the analysis of data. TS, RK and DK helped in the collection of samples and in the laboratory procedures during the research work. All authors read and approved the final manuscript.

\section{Acknowledgments}

This research was a part of thesis in the Department of Veterinary Pharmacology and Toxicology, College of Veterinary Science and Animal Husbandry, NDVSU, Jabalpur, Madhya Pradesh. The authors would like to thank the Vice-Chancellor, Director of Instructions, NDVSU and Dean College of Veterinary Science and Animal Husbandry, Jabalpur, for providing all the facilities necessary for the work. This research was funded by the Department of Veterinary Pharmacology and Toxicology, College of Veterinary Science and Animal Husbandry, NDVSU, Jabalpur, Madhya Pradesh, India.

\section{Competing Interests}

The authors declare that they have no competing interests.

\section{References}

1. Compant, S., Duffy, B., Nowak, J., Clement, C. and Barka, E.A. (2005) Use of plant growth-promoting bacteria for biocontrol of plant diseases: Principles, mechanisms of action, and future prospects. Appl. Environ. Microbiol., 71(9): 4951-4959.

2. Garcia, A., Rhoden, S.A., Rubin-Filho, C.J., Nakamura, C.V. and Pamphile, J.A. (2012) Diversity of foliar endophytic fungi from the medicinal plant Sapindus saponaria L. and their localization by scanning electron microscopy. Biol. Res., 45: 139-148.

3. Strobel, G. and Daisy, B. (2003) Bioprospecting for microbial endophytes and their natural products. Microbiol. Mol. Biol. Rev., 67(4): 491-502.

4. Upma, A., Ashok, K., Pankaj, K. and Tarun, K. (2011) 
The nature's gift to mankind: Neem. Int. Res. J. Pharm., 2(10): 13-15.

5. Elavarasu, S., Abinaya, P., Elanchezhiyan, S., Thangakumaran, S., Vennila, K. and Naziya, K.B. (2012) Evaluation of anti-plaque microbial activity of Azadirachta indica (neem oil) in vitro: A pilot study. J. Pharm. Bioallied Sci., 4(2): 394-396.

6. Xu, J., Song, X., Yin, Z.Q., Cheng, A.C., Jia, R.Y., Deng, Y.X., Ye, K.C., Shi, C.F., Lv, C. and Zhang, W. (2012) Antiviral activity and mode of action of extracts from neem seed kernel against duck plague virus in vitro. Poult. Sci., 91(11): 2802-2807.

7. Alam, A., Haldar, S., Thulasiram, H.V., Kumar, R., Goyal, M., Iqbal, M.S., Pal, C., Dey, S., Bindu, S., Sarkar, S., Pal, U., Maiti, N.C. and Bandyopadhyay, U. (2012) Novel anti-inflammatory activity of epoxyazadiradione against macrophage migration inhibitory factor: Inhibition of tautomerase and proinflammatory activities of macrophage migration inhibitory factor. J. Biol. Chem., 287(29): 24844-24861.

8. Aravindan, S., Natarajan, M., Herman, T.S., Awasthi, V. and Aravindan, N. (2013) Molecular basis of 'hypoxic' breast cancer cell radio-sensitization: Phytochemicals converge on radiation induced Rel signaling. Radiat. Oncol., 8: 46.

9. Abdel-Ghaffar, F., Al-Quraishy, S., Al-Rasheid, K.A. and Mehlhorn, H. (2012) Efficacy of a single treatment of head lice with a neem seed extract: An in vivo and in vitro study on nits and motile stages. Parasitol. Res., 110(1): 277-280.

10. Mahajan, S., Bakshi, S., Bansal, D. and Bhasin, P. (2014) Isolation and characterization of endophytes. Int. J. Lat. Sci. Res. Technol., 1: 29-33.

11. Bauer, A.W., Kirby, W.M.M., Sherris, S.C. and Turk, M. (1969) Antibiotic susceptibility testing by a standerized single disc method. Am. J. Clin. Pathol., 45: 493-496.

12. Kirubaharan, J.J., Paliniswami, K.S., Anubukumar, K. and Subramaniam, M. (1999) In vitro studies on antibacterial effect of crude garlic extract on E. coli. Indian Vet. J., 76: 797-799.

13. Ryan, R.P., Germaine, K., Franks, A., Ryan, D.J. and
Dowling, D.N. (2008) Bacterial endophytes recent development and applications. FEMS Microbiol. Lett., 178: 1-9.

14. Hung, P.Q. and Annapurna, K. (2004) Isolation and characterization of endophytic bacteria in soybean (Glycine sp.). Omonrice, 12: 92-101.

15. Sobral, J.K., Araujo, W.L., Mendes, R., Kleiner, A.A.P. and Azevedo, J.L. (2005) Isolation and characterization of endophytic bacteria from soybean (Glycine max) grown in soil treated with glyphosate herbicide. Plant Soil, 273(1): 91-99.

16. Costa, L.E.O., Queiroz, M.V., Borges, A.C., Moraes, C.A. and Araujo, E.F. (2012) Isolation and characterization of endophytic bacteria isolated from the leaves of the common bean (Phaseolus vulgaris). Braz. J. Microbiol., 43(4): 1562-1575.

17. Ebrahimia, A., Asghariana, S. and Habibianb, S. (2010) Antimicrobial activities of isolated endophytes from some Iranian native medicinal plants. Iran. J. Phram. Sci., 6(3): 217-222.

18. Bahgat, M.M., Bons, M.M.E., Kawashty, S.A. and Ei, N.A.M. (2014) Characterization of endophytic bacteria isolated from the medicinal plants Capparis indica veil and analyse its bioactive flavonoids. Indian J. Appl. Res., 4: 5-13.

19. Verma, V.C., Gond, S.K., Kumar, A., Mishra, A., Kharwar, R.N. and Gange A.C. (2009) Endophytic actinomycetes from Azadirachta indica A. Juss.: Isolation, diversity, and anti-microbial activity. Microb. Ecol., 57: 749-756.

20. Jalgaonwala, R.E., Mohite, B.V. and Mahajan, R.T. (2010) Evaluation of endophytes for their antimicrobial activity from indigenous medicinal plants belonging to North Maharashtra region India. Int. J. Pharm. Biomed. Res., 1(5): 136-141.

21. Roy, S. and Banerjee, D. (2010) Isolation of antimicrobial compound by endophytic bacteria from Vinca rosea. Int. J. Curr. Res., 5: 47-51.

22. Pal, A., Chattopadhyay, A. and Paul, A.K. (2012) Diversity and antimicrobial spectrum of endophytic bacteria isolated from Paederia foetida L. Int. J. Curr. Pharm. Res., 4(3): 123-127. 